\title{
Enhancement of Interleukin-2 Production in CCRF-CEM, Human T-Cell Leukemia, by Tea Flavonols
}

\author{
Kazumi ASAI*, Sawako MORIWAKI and Mari MAEDA-YAMAMOTO \\ Department of Physiology and Quality Science, National Institute of Vegetable and Tea Science \\ (Kanaya, Shizuoka 428-8501, Japan)
}

\begin{abstract}
Human T-cell leukemia, CCRF-CEM, produced interleukin (IL)-2 stimulated with phorbol myristate acetate (PMA) and pokeweed mitogen (PWM). In PMA/PWM stimulation, IL-2 production in CCRFCEM was increased by treatment with kaempferol or quercetin, tea (Camellia sinensis L.) flavonols. In this study, we concluded that (1) flavonols affected the expression of CCRF-CEM surface molecules, (2) CCRF-CEM was activated by flavonols, achieving a state receptive to stimulation, and (3) IL-2 production and mRNA expression were promoted by flavonols.
\end{abstract}

Discipline: Tea industry / Animal industry

Additional key words: tea (Camellia sinensis L.), cytokine, kaempferol, quercetin, myricetin

\section{Introduction}

It has previously been reported that tea (Camellia sinensis L.) has various bioregulatory activities, such as anti-oxidative activity ${ }^{9}$, free radical scavenging activity ${ }^{2}$, anti-bacterial action ${ }^{1}$ and a carcinogenesis inhibitory effect ${ }^{14}$. There have been a lot of studies on the tea polyphenol, especially catechins, which are unique components of tea. A recent report also demonstrated an interesting anti-allergic function of tea catechin ${ }^{12,13}$. Flavonols, kaempferol, quercetin and myricetin are components of tea belonging to a group of polyphenolic compounds, and they are found in fruit, vegetables and tea. They may have beneficial health effects because of their antioxidant properties ${ }^{4}$ and their inhibitory role in tumor development $t^{5}$ in animal studies. However, there have been no studies on the immuno-regulatory effects of flavonols.

$\mathrm{T}$ cells, a type of lymphocyte, function as a control tower in the immune system, and produce cytokine, a protein used by various cells to communicate. IL-2 is one of these cytokines and is called an immune modulator. T cells produce IL-2 when they are stimulated by an infection. IL-2 makes infection-fighting cells multiply and mature. IL-2 is a major autocrine growth factor and contributes to immune responses in part by promoting rapid proliferation of activated $\mathrm{T}$ cells ${ }^{11}$. IL-2 has been approved by the FDA (Food and Drug Administration) for the treatment of some types of cancer, but has not yet been approved for the treatment of HIV (human immunodeficiency virus) disease. IL-2 is the immune-based therapy that has been most extensively studied in HIV.

To clarify whether tea extracts or tea components (catechins and flavonols) affect $\mathrm{T}$ cells or not, we studied T-cell leukemia, CCRF-CEM, and evaluated CCRFCEM cytokine production. In this study, we observed that CCRF-CEM was activated and that IL-2 production was increased by flavonol treatment.

\section{Materials and Methods}

\section{Cells and culture}

CCRF-CEM (CCL-1199) was purchased from American Type Culture Collection (ATCC). Cells were cultured in RPMI 1640 supplemented with $10 \%$ fetal bovine serum in the presence or absence of $10 \mu \mathrm{g} / \mathrm{mL}$ of tea extract (as tannin) or a tea component for $48 \mathrm{~h}$. The cells were washed and then stimulated with $5 \mu \mathrm{g} / \mathrm{mL}$ of PWM and $10 \mathrm{ng} / \mathrm{mL}$ of PMA for $24 \mathrm{~h}$.

\section{Tea extracts}

Tea leaves were harvested at the plantation of the National Institute of Vegetable and Tea Science, in

*Corresponding author: fax +81-547-46-2169; e-mail kazumia@affrc.go.jp

Received 9 July 2004 ; accepted 29 September 2004. 
Kanaya, Shizuoka, Japan, and we used two cultivars of tea, 'Yabukita' and 'Benifuki'. The tea leaves were dried in a microwave and pulverized, and then $10 \mathrm{~mL}$ of distilled water was poured onto $0.2 \mathrm{~g}$ of tea and steeped at $60^{\circ} \mathrm{C}$ for $10 \mathrm{~min}$. The tannin content of the samples was measured using colorimetric determination with ferrous tartrate $^{12}$. Assay tannin content or tea component content (final concentration: $10 \mu \mathrm{g} / \mathrm{mL}$ ) was defined by a cell viability test from $1 \mathrm{pg} / \mathrm{mL}$ to $1 \mathrm{mg} / \mathrm{mL}$. Epigallocatechin gallate (EGCG), epigallocatechin (EGC), epicatechin gallate (ECG) and epicatechin (EC), kaempferol, quercetin and myricetin were purchased from SigmaAldrich.

\section{ELISA for the measurement of IL-2 cytokine production}

The concentration of IL-2 in the culture supernatant was measured by ELISA using BD OptEIA ${ }^{\mathrm{TM}}$ Human IL2 ELISA Set (BD Biosciences).

\section{RNA extraction and quantitative RT-PCR analysis}

Total RNA was isolated from cells using the ISOGEN reagent (Nippon Gene). Reverse transcription was carried out with Ready-To-Go ${ }^{\mathrm{TM}}$ RT-PCR Beads (Amersham Bioscience). The primers used were as follows: $\beta$-actin forward, 5'-TGA CGG GGT CAC CCA CAC TGT GCC CAT CTA-3'; $\beta$-actin reverse, 5'-CTA GAA GCA TTG CGG TGG ACG ATG GAG GG-3'; IL2 forward, 5'-ATG TAC AGG ATG CAA CTC CTG
TCT T-3'; and IL-2 reverse, 5'-GTC AGT GTT GAG ATG ATG CTT TGA C-3'. PCR was performed for 20 cycles of denaturation at $95^{\circ} \mathrm{C}$ for $1 \mathrm{~min}$, annealing at $60^{\circ} \mathrm{C}$ for $1 \mathrm{~min}$ and primer extension at $72^{\circ} \mathrm{C}$ for $1 \mathrm{~min}$. PCR products were separated on $1.2 \%$ agarose gel and visualized by ethidium bromide staining.

\section{Flow cytometry analysis}

CCRF-CEM cells were cultured in the presence of $10 \mu \mathrm{g} / \mathrm{mL}$ of flavonol for $48 \mathrm{~h}$. Cells were then washed and incubated at $4^{\circ} \mathrm{C}$ for $30 \mathrm{~min}$ with the appropriate staining reagents according to a standard method ${ }^{7}$. The reagents used in this study were as follows: anti-CD3-PE, anti-CD4-PE, anti-CD8-PE, anti-CD25-FITC, antiCD69-PE, anti-mouse IgG-PE, and anti-mouse IgGFITC. Reagents were purchased from Beckman Coulter. Flow cytometry analysis was performed on EPICS XL (Beckman Coulter), and their results were analyzed with CELLQUEST software (Becton Dickinson).

\section{Results}

\section{Production of IL-2 cytokine in CCRF-CEM}

To clarify the effect of tea components on the immune system, CCRF-CEM, human T-cell leukemia, was used. IL-2 production was detected in CCRF-CEM stimulated with PMA and PWM. Among the tea components tests, IL-2 production was increased after CCRFCEM was cultured with flavonols, especially kaempferol

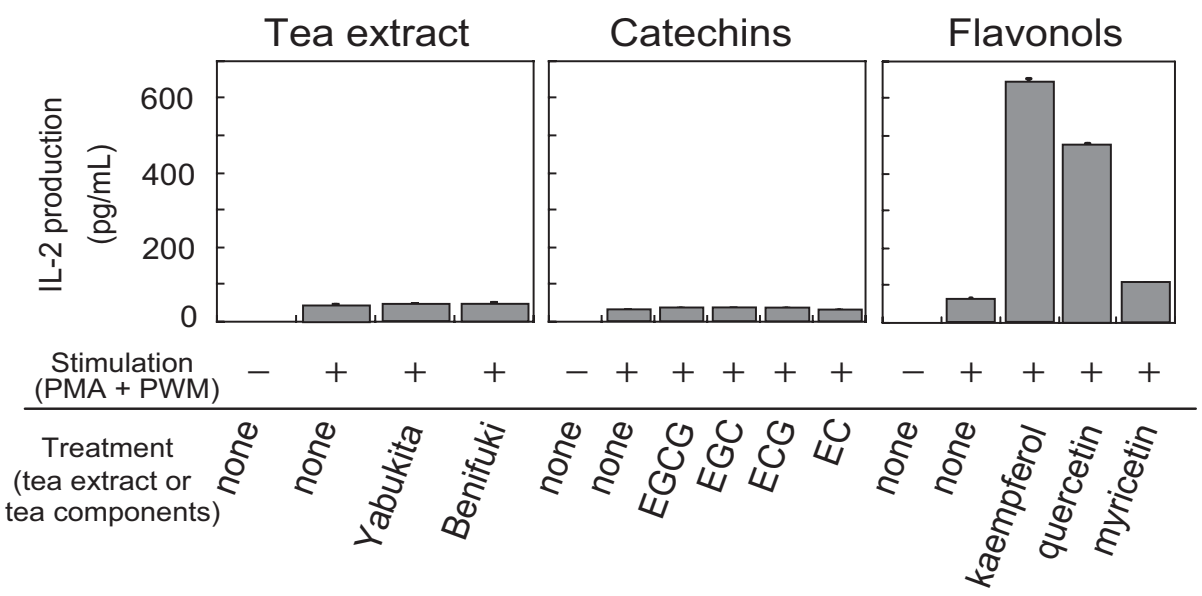

Fig. 1. Flavonols promote IL-2 cytokine production

CCRF-CEM cells $\left(5 \times 10^{5} / \mathrm{mL}\right)$ were cultured with tea extract, catechins or flavonols for $48 \mathrm{~h}$. Cells were then washed and stimulated with PMA $(10 \mathrm{ng} / \mathrm{mL})$ and PWM $(5 \mu \mathrm{g} / \mathrm{mL})$ for $24 \mathrm{~h}$. Mean IL-2 cytokine production in each culture is shown with the standard deviation. Data represent the results from at least four independent experiments. 
and quercetin (Fig. 1). However, tea extract from 'Yabukita' as well as 'Benifuki' and catechins (EGCG, EGC, ECG and EC) did not affect IL-2 production.

\section{Expression of IL-2 mRNA in CCRF-CEM}

We next examined the capacity of flavonols to enhance IL-2 mRNA expression. To determine the level of mRNA for IL-2 in CCRF-CEM cells, we performed quantitative competitive RT-PCR. When CCRF-CEM was treated with kaempferol or quercetin and stimulated by PMA/PWM, the IL-2 mRNA expression of these cells was upregulated. The potency of flavonols in enhancing steady-state IL-2 mRNA expression was similar to that observed in enhanced IL-2 protein synthesis (Fig. 2b).

\section{Expression of CD molecules in CCRF-CEM}

IL-2 is a major autocrine growth factor for $T$ lymphocytes ${ }^{9}$. It exerts its growth-promoting properties after interaction with specific membrane binding sites (IL-2 receptor $\alpha$ chain: CD25) expressed on activated, but not on resting, $\mathrm{T}$ cells ${ }^{10}$. We then estimated that surface molecules of CCRF-CEM were changed by fla- vonol treatment. We expected that the expression of CD25 was increased by kaempferol or quercetin treatment, so we investigated the expression of CD25 on CCRF-CEM. However, the CD25 expression did not increase by flavonol treatment.

We then investigated the expression of other molecules, CD3, CD4, CD8 and CD69 on CCRF-CEM. CD3, CD4 and CD8 molecules were T-cell specific markers, and CD69 was an activated T-cell marker. It was clear that the CD69 expression of CCRF-CEM was increased by kaempferol or quercetin treatment in synchronized IL2 production and mRNA expression. Furthermore, CD3 expression was increased by flavonols, especially quercetin, showing that CCRF-CEM was activated by flavonol treatment. Conversely, CD4 and CD8 expressions were hardly affected by flavonol treatment (Fig. 3).

\section{Discussion}

To clarify the immunoregulatory effects of tea extracts and components on T cells, we analyzed cytokine production using human T-cell leukemia, CCRF-
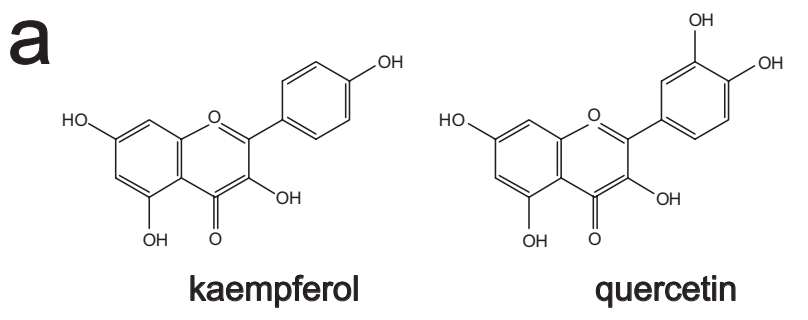

quercetin<smiles>O=c1c(O)c(-c2cc(O)c(O)c(O)c2)oc2cc(O)cc(O)c12</smiles>

myricetin

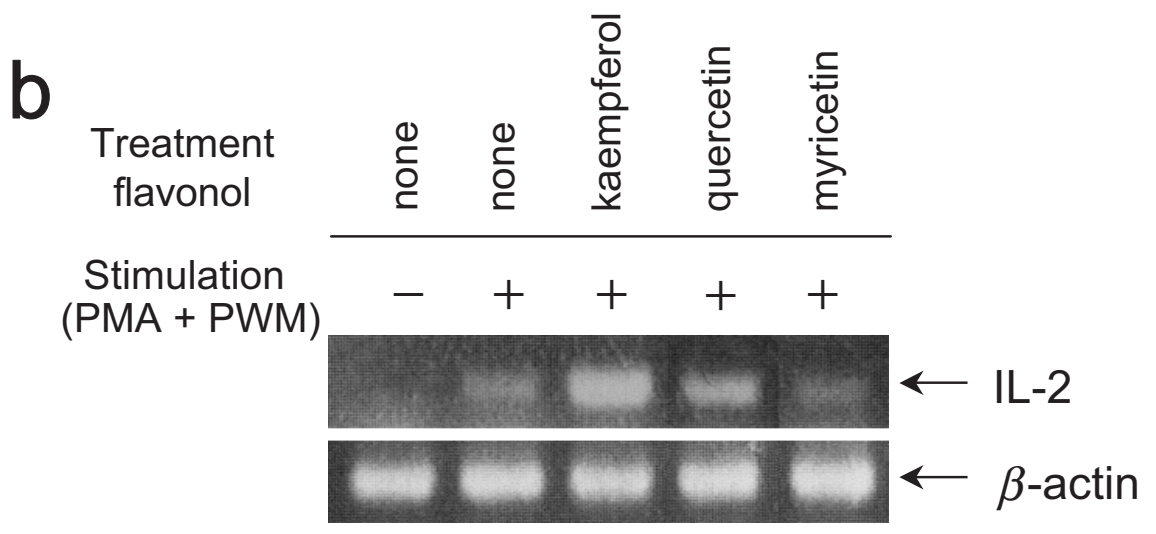

Fig. 2. Structure of flavonols and PMA+PWM stimulation of CCRF-CEM cells a: Structure of flavonols; kaempferol, quercetin and myricetin.

b: CCRF-CEM cells $\left(5 \times 10^{5} / \mathrm{mL}\right)$ were cultured with flavonols for $48 \mathrm{~h}$. Cells were then washed and stimulated with PMA $(10 \mathrm{ng} / \mathrm{mL})$ and PWM $(5 \mu \mathrm{g} / \mathrm{mL})$ for $24 \mathrm{~h}$. After harvesting the cultured cells, total RNA was extracted. mRNA levels of IL-2 and $\beta$-actin were determined by RT-PCR analysis with template cDNA. Three independent experiments were performed with similar results. 


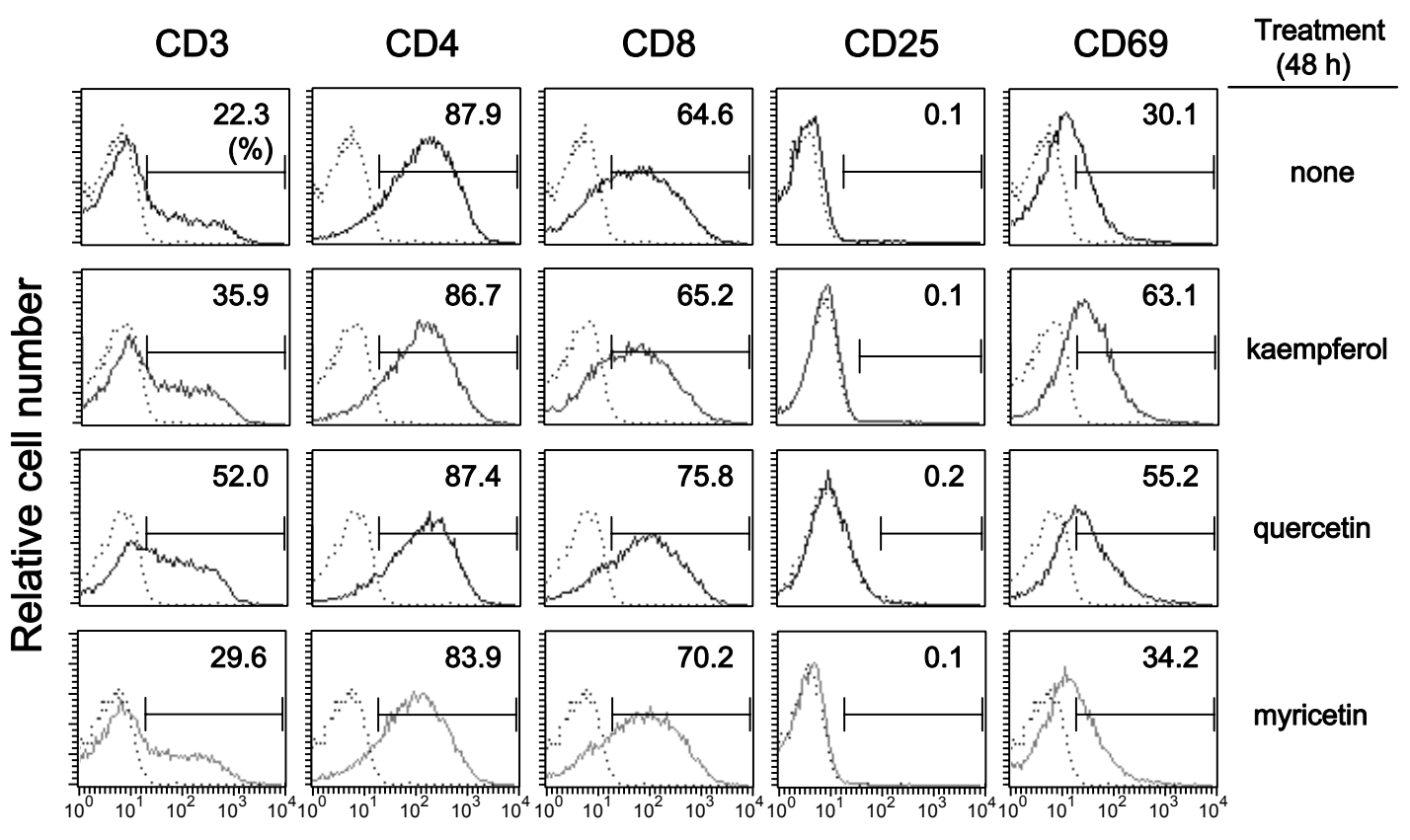

Fluorescence

Fig. 3. Expression of the surface molecules on CCRF-CEM cells

CCRF-CEM cells were cultured with flavonols for $48 \mathrm{~h}$. After harvesting the cultured cells, cells were stained by anti-CD3, anti-CD4, anti-CD8, anti-CD69 and anti-mouse IgG PE conjugated antibodies or anti-CD25 and anti-mouse IgG FITC conjugated antibodies. The percentages of positive cells are shown. Dotted line: control.

CEM. When CCRF-CEM was stimulated by PMA and PWM, the cells produced IL-2. It is essential that IL-2 regulates T-cell proliferation and survival for correct homeostasis in the immune system. We first analyzed whether the IL-2 production level was influenced by tea extracts or components. As shown in Fig. 1, the IL-2 production level was not changed by tea extracts or catechins, showing that they had no effect on CCRF-CEM. In this study 'Yabukita' tea extract contained EGCG, EGC, ECG and EC in concentrations of 26.5, 43.5, 5 and $14.5 \mathrm{mg} / \mathrm{L}$, respectively. 'Benifuki' tea extract contained EGCG, EGC, ECG and EC in concentrations of 34, 38, 8.3 and $11.5 \mathrm{mg} / \mathrm{L}$, respectively. However, in flavonol treatment, especially kaempferol or quercetin, IL-2 production was significantly increased, whereas myricetin had no effect on IL-2 production. Furthermore, as shown in Fig. 2, because the IL-2 mRNA level was increased with kaempferol or quercetin, it is conceivable that flavonols influence cell signal transduction and enhance CCRF-CEM cell IL-2 production at a transcriptional, or posttranscriptional level. We didn't analyze for flavonols, so we didn't know the concentrations of kaempferol, quercetin and myricetin in tea extracts of, 'Yabukita' and 'Benifuki' used in this study. It was necessary to refer to other research for the concentrations of kaempferol, quercetin and myricetin in green tea which were 15,23 and $12 \mathrm{mg} / \mathrm{L}$ respectively, when $5 \mathrm{~g}$ of Sencha was placed in $500 \mathrm{~mL}$ of boiling water for $5 \mathrm{~min}^{3}$. However, we did not clarify why different influences were observed between kaempferol or quercetin and myricetin. Recent reports showed that kaempferol suppressed interferon- $\gamma$ and IL-2 production in an in vivo experiment ${ }^{8}$. These results differ between in vivo and in vitro experiments, so it is necessary to analyze more in vitro experiments using T-cell leukemia.

CCRF-CEM treated with kaempferol or quercetin showed a higher level of CD69 and CD3 expression as compared to the non-treatment group. CD69 expression was TCR (T-cell receptor)-dependent and CD3 bound to TCR. Therefore it was conceivable that CCRF-CEM was sensitized with kaempferol or quercetin through the TCR, and CCRF-CEM was in an activated state. However, CD25 was not affected by flavonols, because its expression was not TCR dependent and it may have other pathways. CD4 and CD8 were T-cell subset markers, so it was conceivable that flavonols did not affect the T-cell phenotype.

We therefore conclude that CCRF-CEM was activated by flavonols, kaempferol or quercetin, achieving a state receptive to stimulation, and the IL-2 production 
and mRNA expression were significantly increased. However, the mechanism of the influence of flavonols on cells has not been fully elucidated. We are currently extending our tea physiological studies in a further effort to clarify these mechanisms.

\section{Acknowledgements}

This research was supported financially in part by the O-CHA Pioneer Academic Research Grant Program of the World Green Tea Association.

\section{References}

1. Amarowicz, R., Pegg, R. B. \& Bautista, D. A. (2000) Antibacterial activity of green tea polyphenols against Escherichia coli K 12. Nahrung, 44, 60-62.

2. Bors, W. \& Saran, M. (1987) Radical scavenging by flavonoid antioxidants. Free Radic. Res. Commun., 2, 289294.

3. Hertog, M. G. L., Hollman, P. C. H. \& Putte, B. (1993) Content of potentially anticarcinogenic flavonoids of tea infusions, wines, and fruit juices. J. Agric. Food Chem., 41, 1242-1246.

4. Hollman, P. C. H. \& Katan, M. B. (1999) Health effects and bioavailability of dietary flavonols. Free. Radic. Res., 31, S75-80.

5. Hollman, P. C. H., Feskens, E. J. \& Katan, M. B. (1999) Tea flavonols in cardiovascular disease and cancer epidemiology. Proc. Soc. Exp. Biol. Med., 220, 198-202.

6. Iwasa, K. \& Torii, H. (1962) A colorimetric determina- tion of tea tannin with ferrous tartrate. Stud. Tea, 26, 8791 [In Japanese].

7. Nakayama, T. et al. (1990) Inhibition of T cell receptor expression and function in immature $\mathrm{CD} 4^{+} \mathrm{CD} 8^{+}$cells by CD4. Science, 249, 1558-1561.

8. Okamoto, I. et al. (2002) The flavonoid kaempferol suppresses the graft-versus-host reaction by inhibiting type 1 cytokine production and $\mathrm{CD} 8^{+} \mathrm{T}$ cell engraftment. Clin. Immunol., 103, 132-144.

9. Okuda, T. et al. (1983) Studies on the activities of tannins and related compounds from medicinal plants and drugs. I. Inhibitory effects on lipid peroxidation in mitochondria and microsomes of liver. Chem. Pharm. Bull., 31, $1625-1631$.

10. Robb, R. J., Munck, A. \& Smith, K. A. (1981) T cell growth factor receptors. Quantitation, specificity, and biological relevance. J. Exp. Med., 154, 1455-1474.

11. Robb, R. J., Greene, W. C. \& Rusk, C. M. (1984) Low and high affinity cellular receptors for interleukin 2 . Implications for the level of Tac antigen. J. Exp. Med., 160, 1126-1146.

12. Sano, M. et al. (1999) Novel antiallergic catechin derivatives isolated from oolong tea. J. Agric. Food Chem., 47, 1906-1910.

13. Tachibana, H. et al. (2001) Identification of an inhibitor for interleukin 4-induced epsilon germline transcription and antigen-specific IgE production in vivo. Biochem. Biophys. Res. Commun., 280, 53-60.

14. Wang, Z. Y. et al. (1992) Inhibition of N-nitrosodiethylamine- and 4-(methylnitrosamino)-1-(3-pyridyl)-1-butanoneinduced tumorigensis in $\mathrm{A} / \mathrm{J}$ mice by green tea and black tea. Cancer Res., 52, 1943-1947. 